\title{
Meaningless vs. Worthwhile Encounters?: Sustaining Social Interactions in Privatized Public Spaces of Manila Shopping Malls
}

\author{
Rowena Capulong Reyes* \\ Far Eastern University, Manila Nicanor Reyes Street, Sampaloc, Manila \\ *Corresponding author: rcreyes@feu.edu.ph
}

\begin{abstract}
Privatized public spaces like modern shopping malls apply various spatial regulations to its mall goers that ultimately, according to scholars of critical tradition, undermines the "social" in socialization during human interactions. This recurring idea is prevalent and proven in a number of developed countries while, on the other hand, research on the same outcome in developing countries such as the Philippines is lacking. Based on local experiences, there is an indication of the possibility of an active associational life within the regulated spaces of the Philippine private shopping mall. This paper tries to determine the circumstances under which spatial governmentality sustains social interaction. Using Robert Yin's case study method, it delves into the spatial practice of mall users in three shopping malls in the city of Manila. Data are gathered from field observations and interviews with the managers and security officers of the three malls. Purposive mall users can evade the disciplinary, deterrence, and exclusionary techniques of the shopping mall and thus pursue their own social activities and interests in the presence of three facilitators: persons, locales and occasions. The cases involved in this study reveal that efforts to control social activities in mall premises can also generate unintended outcomes, that is, activate social activities.
\end{abstract}

Keywords: Social interaction, shopping malls, spatial governmentality

(C) 2016 Penerbit UTM Press. All rights reserved

\subsection{INTRODUCTION}

The transfer of power and responsibilities to local government units following the promulgation of the Local Government Code of 1991 has opened up myriad opportunities for local authorities to be inclusive and entrepreneurial in developing their capacities for public service provision [1-2]. Thus, a common trend right now in local government administration is the pursuit of efficiency and competitiveness, that is, the generation of social goods at the least possible costs for the tax-paying public. This phenomenon is not exclusive to the Philippines; it is a global trend, in fact. All over the world, local governance institutions are increasingly becoming more concerned about developing and maintaining their economic competitiveness in order to attract and retain capital investments [3-4].

This drive for efficiency has brought notable changes to the social order of thriving urban centers, in particular, to the management and organization of public spaces [5-7]. The emphasis of the local governments on income generation and cost-cutting measures has drastically reduced government support for traditional open spaces like public parks and playground. It also has led to the adoption of has led to the adoption of privatization of public spaces - which explains the proliferation of private shopping malls in the urban centers of the country [8-9].

It is believed that handing down the responsibility of managing public spaces to private management will bring positive effects as it increases the quality of management and service [10] which in turn would increase quality of life [11]. But there are those who

contend that the phenomenon of privatization of public spaces has adverse effects on the associational life of the mall users. According to Ploeg [12], "Privatization of public space is generally achieved through the transfer of the maintenance, security, or management rights of a space to a private entity like a business association, development corporations or homeowners association. When private interests provide security or make rules for a public space, they can directly or indirectly exclude certain groups or types of people." The reason for this is that they become ultimately the basis for what should be part of the "public". Normally, the interest of the private sector - profitability - depends on its ability to pursue spatial control or what private planners and designers refer to as "good management". A well-ordered public space results in greater opportunities for consumption and leisure and thus profit. Yet this reduces dramatically spaces for individual self-fulfillment [13] and ultimately to undemocratic outcomes [14-16].

The emergence of privatized public spaces like shopping malls as a popular alternative to traditional government-managed public spaces such as parks has been a major concern among critical scholars of public life since the 1990s [17]. Most of these scholars analyze the experiences in urban centers of Anglo-American societies. Though, they correctly identified the exclusionary proclivities of modern spatial regulations, they are mistaken in assuming the universality of their findings [18-19]. The pessimistic assumptions about the implications of spatial governmentality to public and social affairs reflect experiences exclusive only to Anglo-American societies and thus cannot fully account for the state of public life in public spaces outside of this context [16]. In addition, talks of decline of public life as a lamentable and inevitable consequence of the privatization of public spaces preclude the possibility of a more optimistic outcome [20-21]. Even in some highly regulated public spaces designed for consumption and leisure countless opportunities for social interaction open up and are taken advantage of by their users on a daily basis [22].

In the city of Manila, recent years have witnessed rapid deterioration of public parks - once the site of the most important political gatherings and glamorous social events - occurring alongside the proliferation of shopping malls. As a consequence, more and more people are relocating their social activities to the much safer, cleaner, comfortable, and stylish confines of privately-ran shopping malls. Yet there remains a dearth in terms of description and analysis regarding the connection between how these private built environments are governed and the quality of associational sphere inside them. Does the spatial governance of private shopping malls in a developing country like the Philippines, similar to what has been observed in Anglo-American urban 
settings, hollow out the associational life of mall users? Thus the question it attempts to answer is: How does spatial governance affect the social life of mall users of private shopping malls in the city of Manila?

\subsection{METHOD}

\subsection{Design and Research Site}

The purpose of this section is to analyze the implications of spatial governance practices applied inside the public spaces of three shopping malls in the city of Manila to the associational activities of people who regularly access them. To accomplish this task, this research undertaking uses multiple case study method. The choice of case study as a method is inspired by the explanation of Merriam [23]. According to Merriam[23], case study is an ideal design for understanding and interpreting observations of social phenomena... [it] is a design particularly suited to situations where it is impossible to separate the phenomenon's variables from their context". In this study, the phenomenon it seeks to understand is the associational life of mall users and the context is private public spaces of the shopping malls.

The study analyzes three shopping malls in the city of Manila, namely: Robinson's Place in Ermita, Harrison Plaza in Vito Cruz, and Tutuban Center in Divisoria. These malls cater to different socioeconomic sections of the population and thus represent different types of "public" and diverse responses to spatial control and restriction practices. An examination of some activities in these privatized public spaces can underscore the dynamics and impact of spatial governance to social interactions in these regulated public spaces.

Describing socio-spatial experiences in these private shopping malls required field observations. The researcher took notes and mapped the pertinent activities using video camera to register the evidences of those activities. For a three-month period, the researcher spent a whole day for each location, during working days and weekends from the opening of the establishment, $10 \mathrm{am}$, till closing, $10 \mathrm{pm}$, observing the behavior of mall-goers and even participating in their social activities, e.g., dining, strolling, etc. This was meant to facilitate a good cross comparison of uses of public spaces and behaviors of mall users and also, to borrow from Snow and Morrill [24], to secure "a close approximation of the empirical world", in this case, the playing out of social life inside the shopping malls.

\subsection{Data Collection and Ethical Consideration}

This study relies on verbal as well as observational evidence to clarify the connection between spatial governmentality and the status of public life in three privately managed shopping malls in Manila. To gather data and information, the researcher conducted a two-fold strategy. The first one involved interview with eight mall users. Interview questions raised were open-ended to encourage respondents to express freely their insights and for the interview sessions to assume a conversational manner. For Kvale [25], such mode of interview allows the researcher a greater chance to capture, understand and interpret not only experiential data but also the context of the experience itself. The second one involved taking photographs and video recording. In the view of this researcher, photographs and video recordings can help describe the significant features of the case study to readers and observers [26].

The researcher duly informed the respondents that conversations were audio and video recorded for documentation and analysis purposes.

\subsection{Mode of Analysis}

In most of social science research, discovery of themes is imperative in the analysis of qualitative data. According to Ryan and Bernard [27], "[w]ithout thematic categories, investigators have nothing to describe, nothing to compare and nothing to explain." Analysis of qualitative data requires the discovery of themes. As used by this researcher, taking the lead of Neumann [28], analysis of qualitative data entailed, first, open coding. After going through several times with observational and analytic notes as well as the interview transcript, statements pertaining to the mall users' social interactions within the shopping spaces of the aforementioned malls are consolidated. Initial codes were extracted from them. This is followed by axial coding. Initial codes identified were reviewed and examined to develop core themes. The last step entailed selective coding, in which data supporting he themes developed are selected.

Descriptions of the status of associational life in one shopping mall were then examined in comparison to those of the other two shopping malls using pattern matching. Yin [26] describes pattern-matching logic as "one of the most desirable techniques for case study analysis." The technique is used to establish coincidence or replication and draw solid conclusions about the effects of the private malls' spatial governmentality on the associational life of mall users in the Philippine context. It allows the researcher to evaluate whether or not the expected outcomes as described in the literature -increased social control in the part of the mall operators and eroded civic culture and resistance to spatial discipline or control mechanism in the part of the mall users - are realized in each of the research site.

\subsection{FINDINGS}

The study takes a critical look into the dynamics of associational life inside the regulated spaces of three Manila shopping malls to determine whether spatial control practices indeed negatively impact the quality of social interaction and encounter between and among mall users. Qualitative data suggest that although these shopping malls exhibit disciplinary, deterrent, and displacement forms of spatial governance similar to that observed in the malls of AngloAmerican societies, apparently, at the same time, they have managed to serve as purveyors of active associational life. This goes to show that even within highly regulated public spaces social ties and community life can thrive. The reason for the prevalence of active associational life despite spatial restrictions in the malls is the presence of facilitating persons, facilitating locales, and facilitating occasions. These factors activate social interaction within a highly regulated space as shown in Table 1. 
Table 1 Conditions for an active social life

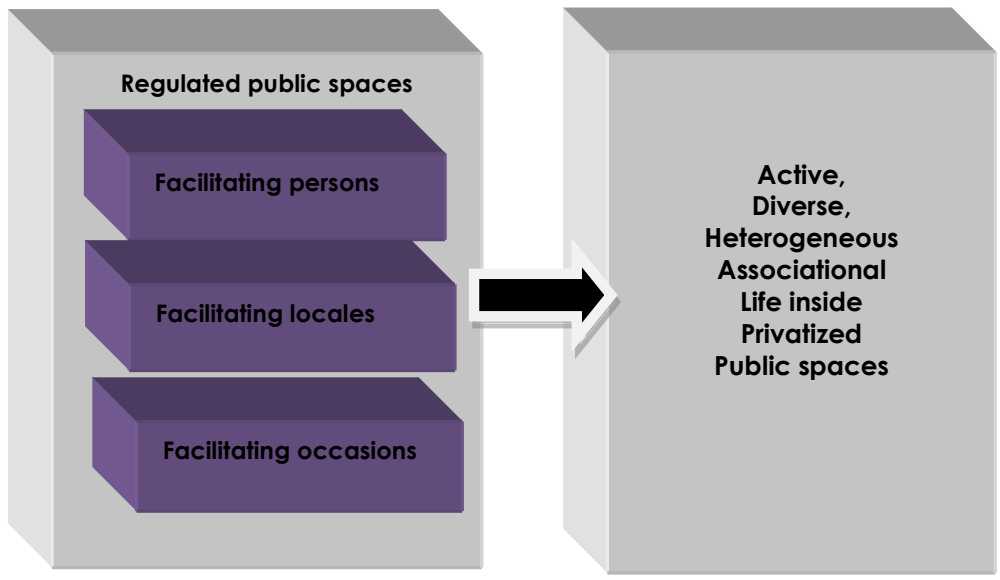

Table 2 Spatial experiences in shopping malls

\begin{tabular}{llll}
\hline Mall & $\begin{array}{l}\text { Spatial } \\
\text { Governance }\end{array}$ & $\begin{array}{l}\text { Presence of } \\
\text { facilitating } \\
\text { persons, locales, } \\
\text { occasions }\end{array}$ & $\begin{array}{l}\text { Active } \\
\text { associationa } \\
\text { I life }\end{array}$ \\
\hline $\begin{array}{l}\text { Robinson's } \\
\text { Place }\end{array}$ & High & YES & YES \\
$\begin{array}{l}\text { Tutuban } \\
\text { Center }\end{array}$ & High & YES & YES \\
$\begin{array}{l}\text { Harrison } \\
\text { Plaza }\end{array}$ & Low & YES & YES \\
\hline
\end{tabular}

\subsection{Facilitating Persons}

In a regulated public space like the shopping mall actions are normally monitored and restricted to support a socio-spatial order conducive to leisure and consumption. As such, the mall culture prescribes everybody to treat everybody else as consumers or as shoppers. However, these spatial practices do not always realize such hegemonic project. Under certain conditions, mall users can elude the mall security's overbearing control practices and actually initiate social activities these very practices often target for restriction and even removal. One of these conditions is the presence of facilitators. Table 2 shows the level of spatial experiences in the three selected malls in Manila.

Facilitators are those persons whose presence ease off tight spatial control and therefore enable mall users to use mall spaces in ways that fit their needs and preferences. The children and the elderly are good facilitators. They can easily activate social exchanges among friends, acquaintances, and strangers. Children are more predisposed to casual conversations and informal activities with strangers and fellow children owing to their affable nature. Aside from that they are not conscious of the stiff formal rules of the mall spaces. This is especially true since, normally, they are not targeted by the mall's security regulations for monitoring and surveillance as it is unlikely for them to spark disruptive conducts. More often than not security personnel simply overlook many of their acts on the account of their age.

The presence of facilitators in common areas of the malls help "loosen up" these "tight", regulated spaces. For instance, in the case of Robinson's Mall, the giant Christmas tree at the center of the mall lobby which was set up intentionally for decorative reason double as a "social hall" where children and the elderly congregate and interact. As shared by a visitor in the mall: "In here, you can sight-see without spending anything, you can enjoy cold temperature without spending anything". 'As for the Christmas tree, you see the kids love it, that's why I bring them here. And my kids also have playmates... Actually I already met another mom who stays here too." Similarly, in Harrison Plaza, one frequent mall user describes: "I just live near here [in Leveriza]. In Harrison Plaza, we enjoy the air-conditioning, and you can just stay here. There are people who just play checkers and chess. Sometimes, I bring the board myself and I never run out of opponents... Truth be told, I'm already friends with the people who stay here often. We see each other every day"

The same condition is observable in Tutuban Center. As verbalized by a one mall user: "[You see] Those kids over there, I teach those kids arnis. We go here to practice with other arnis groups...every Saturday and Sunday we go here to enhance our skills, especially for those who want to obtain a belt and also, to show solidarity with other arnis groups."

\subsection{Facilitating Locales}

Inside the mall there are locales which allow mall users to mutually access each other and interact for purposes other than commercial exchange. These are what in this study are referred to as facilitating locales. In these locales, one may not treat the other as "customer" or "shopper" but as an individual capable of identifying with another social being. Examples of these facilitating locales are the food courts, nodes, and common areas. The use of these locales facilitates informal encounters among complete strangers which may lead mall user to freely "reinterpret" the uses and functions of these privately regulated spaces. Just being there exposes themselves to chance conversations with other mall users.

However, social encounters here are not limited to verbal exchanges between and among friends, acquaintances or strangers. They include as well hand signals, facial expressions or bodily gestures signifying one's recognition of the presence of the other. For instance, as observed by this researcher in all of the three malls, during lunch time when the food court is overwhelmed with activity, people mix up that strangers often bump into one another, inciting spontaneous trade of curt verbal and non-verbal expressions. Sometimes, they share a single table where, while having lunch, they exchange simple yet polite gestures with each other. 
In Tutuban Center, the mall management developed a function area for healthful activities, such as aerobics and martial arts like arnis, complete with physical structures like inclined bars and swings. The mall itself sponsors events to promote these group activities, even organizing an aerobics club. The activities are open to everyone, and the use of the place is absolutely free. Every morning friends and strangers alike come to this place to jog, exercise, and later mingle with each other. According to a jogger: "They opened up this place so that the public could exercise here, free of charge. Every Saturday, we go here and meet-up with the others. We are actually going to start an official aerobics club so that our group would be formal."

\subsection{Facilitating Occasions}

As part of their spatial governance, the mall management installs props or architectural designs in an effort to create a sophisticated and consumerist mall ambience. By design, sets of furniture and art decorations are commonly used to adorn the dull spaces of the mall. Unintentionally, though, the presence of these props and designs stir occasions of public socialization. Their presence encourages complete strangers to talk to each other as though they are not strangers.

In all of the three malls, benches in their respective common areas constantly invite mall users to sit down and relax. In one of her field visits in Robinson's Place, this researcher observed that some of those who sit in these benches initiate small chats with strangers next to them by asking for time or asking for direction. In Harrison Plaza an old man seated on the bench asked another old man comfortably sitting beside him and reading his tabloid if he could share a page of what he was reading. In Tutuban Center, art works on display in the museum became an occasion for strangers to utter and exchange a few words to each other regarding the history of the place or their opinion about the people or the event depicted in the paintings.

\subsection{DISCUSSION}

Public spaces perform a very essential social function. Generally, they serve as "geographical and symbolic centers" for human interaction [29]. By creating avenues for members of a community to meet and interact, public spaces generate opportunities to forge social ties [30] (Volker, Flap \& Lindenberg, 2007) Aside from being an environment for social interaction, they also are a locus of power relations [31-33]. It is in public spaces "where 'the public' is formed and thus social and cultural rules governing public behavior predominate" [16]. As such, whoever controls these spaces controls the production and reproduction of certain rules of the social or political game including the process of social interaction.

The literature in political geography views public space as an essential precondition for the health and sustainability of democratic societies. Susan Bickford [34] explains: "We can see that [public space] is also significant as a space of attention orientation, a space that shapes citizens' sense of what people, perspectives, and problems are present in the democratic public". Critics contend however that the democratic potentials of public spaces are exploited by the upper section of society (the middle/upper classes, business owners, government along with those with decision-making powers) to redefine the meaning of public space - who belongs to the "public" and how should public space function - with the end in view of promoting their own power and economic interests. This is often done through privatization.

Yet by privatizing the management of public spaces, it is argued that social engagements played out within them become limited and heavily regulated to increase consumerism, thereby decreasing democratic expressions and social interaction [35]. Some even boldly claim that it signifies "the death of the social" [36]. For these scholarships, the spatial regulations of contemporary privatized public spaces like the modern shopping malls strips the "social" out of human interactions by denying their users bases for socialization [14,36-38]. This is so because these control techniques, through coercion or subtleties, program mall users to identify themselves not with other social actors but with the culture of commodity consumption being promoted by the planners and private managers of these public spaces [15,39-40]. Moreover, they are deployed on purpose to maintain a socio-spatial order in which access and enjoyment is available only to those who have the ability to pay while keeping out actors and functions deemed distractive to the mall's consumerist operation[16, 4145]. Thus, in view of their asocial and discriminatory orientation, contrary to what public spaces are in the past, private shopping malls do not and cannot serve as a context for meaningful public life [43, 46-48].

Interestingly, the evidence gathered from the three research sites presents a relatively more optimistic sight. In all of these cases - Robinson's Place, Harrison Plaza, and Tutuban Center - it was observed that the spatial design and order themselves, under certain conditions, empower mall users to utilize mall spaces not just for consumption and leisure but for satisfying the requirements of socialization as well. This is consistent with the findings of some scholars which describe public spaces as, to use Amin's [49] term, "sites of civic promise". The spatial governmentality of the mall therefore does not invariably chisel passive observers and thoughtless consumers out of the mall users.

Moreover, the findings point out the inadequacy of focusing too narrowly on the negative impacts of hard social control on socialization inside shopping spaces while discounting completely the possibility of it generating positive effects. Regulated public spaces may provide a safe and secured context for social engagement to take place. Without first securing safe conditions for people to meet, socialization will never take place. In this case, restrictive spatial governance contributes to the active socialization of mall users [50].

There has been a growing research on how privatized public spaces improve the physical, emotional and social well-being of their users. Physically and emotionally, these public spaces can potentially serve as "therapeutic landscapes"[51] or "restorative places" [52]. By providing a physical context for social interaction, those who access them tend to feel better about themselves and about their ties with others like peers, friends, families [53]. Furthermore, as people find happiness in collective activities played out in public spaces, stress and anxiety are said to be moderated, thus contributing to the maintenance of physical health as well as recovery from melancholy [54-55]. Socially, recent researches suggest that public spaces can be instrumental in the promotion of social capital. As the work of Francis, Giles-Corti, Wood \& Knuiman [56] shows, sense of community is significantly associated with public spaces like shops and community centers. Joung and Miller [57] explains, "shopping centers often provide places where people meet friends, pass time, watch people and engage in other aspects of social exchange."

As what the spatial experiences in the three malls studied here indicate, the public spaces inside the shopping malls generate conditions for mall users to develop their physical and social well-being by simply providing them occasions to interact. In the case of Robinson's Mall, as this researcher experienced in one of the common areas, the presence of enabling occasions, i.e., the giant Christmas tree, Christmas carols as background music, children playing around, encouraged complete strangers to congregate as well as interact by exchanging smiles and pleasantries. These simple and often taken for granted symbols of encounters have therapeutic qualities or, in the words of Stockdale, Wells, Tang, Belin, Zhang, \& Sherbourne [58], "stress buffering mechanisms".

The same is true in the case of Tutuban Center. Here, the mall management itself designed spaces to encourage the active participation of its patrons in healthful social activities. For instance, the managers opted to develop the wide vacant spaces beside the mall building into a function area for healthful activities, such as aerobics and martial arts like arnis, complete with physical structures like inclined bars and swings. The mall itself sponsors events to promote these group activities, even organizing an aerobics club. Moreover, Tutuban Center, on special occasions, opens a portion of its space to free speech especially political speech and nationalistic expressions - an unprecedented move given the restrictive nature of the private shopping malls. Recently, the mall management issued a memorandum enjoining employees and tenants to participate in the flag raising ceremony every Monday morning in front of the main shopping center where the statue of Andres Bonifacio stands. The mall management even allowed some left-leaning groups - well-known for their anti-establishment and anti-capitalist sentiments - to congregate in front of the shopping center and stage a political gathering to peacefully commemorate the birthday of the "Father of Philippine Revolution". In this case, the mall itself allowed its premises to serve as a venue for the expression of the political 
ideals of the gathered crowd. Leaflets and flyers were distributed while speeches were delivered throughout the demonstration. Popular politicians even attended and addressed the crowd.

In the same vein, the socially-enabling design of Harrison Plaza facilitates the wellbeing of its users. Many of the users of the lobby are "facilitators" elderly persons who mostly are from the nearby communities of informal settlers and who frequent the place to avail of the amenities of the mall, e.g., airconditioning and rest rooms, for free. The benches in the lobby give them a perfect place to play board games, sleep, chat and gossip about everything. Since adjacent to the lobby is an appliance center, mall users also get free entertainment. Accordingly, the crowd sitting on the benches of the lobby is encouraged to stay longer and feel at home. There was an instance during one of this researcher's field visits when an appliance store played a full-length movie in one of the television sets on display. A crowd of by-standers - they do not know each other - gathered in front of the store and enjoyed watching the film as if they were in front of their own television set and sitting on the couch of their own living room. From time to time the strangers spoke a few words to each other about the film they were seeing as if they knew everyone very well. The case of Harrison Plaza demonstrates clearly how a privatized public space can, although inadvertently, enable particularly the less fortunate through the material properties of its shopping spaces compensate their "diminished functional resources and capabilities" [59].

Another interesting observation about the spatial condition of these shopping malls is its being a social construction. Space is basic element of human experience and the conduct of everyday life. It does not only refer to a built environment which serves as physical context of human activities; it also pertains to "an active and constitutive presence, shaping habits and interaction and situating or grounding all experiences" [60]. Yet it also is open to reinterpretation by enterprising individuals and thus can be itself constituted or reconstituted according to their desires and preferences. As the spatial experiences in these malls prove in Table 2, mall users may respond to their spatial context by creating in their own way, borrowing from Lynch [61]"a space full of openness without social and economic constraints" and try to produce a social experience that defies the original intention or commercial interests of the dominant forces of the mall. Interpreting the purpose and use of public spaces according to the mall users' own preferences by engaging in social activities wherein they could identify and realize their best potentials in turn "produces a feeling of personal expressiveness" and thus experiences of greater wellbeing [62].

For instance, Robinson's Place demonstrates high degree of spatial governmentality and therefore social control. Spaces are disciplined by extensive private security forces, monitored by panopticon devices directed at the containment of potential nuisance and troublesome people and conduct. In other words, it is here that exclusion and most especially the subjection of personal and collective behavior under the private interests is strongest. Nonetheless, mall users still manage "to act out of place", that is defy the rules and in the process create and represent a public space distinct from the original vision of the mall's private planners and managers. This is possible because embedded in the spatial order of the mall are enabling properties which inevitably activates associational outcomes once capitalized on by enterprising mall users.

As in the case of Robinson's, the public spaces of Harrison Plaza is subject to reinterpretation and reconstruction by it users. Specific part of the mall has been "taken over" by its users and converted it into their own living room of some sorts. Given the background of the most of them, many of these mall users do not intend to buy anything from the store. They were there simply to avail of the amenities of the mall. In other words, many of the mall-users behave more like "transient boarders" than paying customers. However, because of the spatial design and the environment surrounding the lobby, it became an enabling locale, an "interactive compound" where mall-users from different walks of life, friends and complete strangers alike, do not just passively sit out the hours but also put on display their personal values. Though it was never the plan of the private mall designers and managers to attract people who could "colonize" the lobby, the mall-users "appropriated" the place and imposed their own rules and version of order as though it was their "own" public space. Moreover, aside from being a built environment for commercial exchange, the mall serves as well as a refuge for many who, because of their socioeconomic conditions, are denied of the same favorable spatial context elsewhere.

Just like all the other private shopping malls, the management of Tutuban Center set up strategies for social control to secure the mall premises given the notoriety of the communities surrounding it as well as the socioeconomic profile of the mall's patrons. However, because of its historical significance Tutuban Center has developed a unique form of spatial governmentality. The outcomes of the mall management's spatial governmentality unintentionally generated enabling occasions for socialization. Through these empowering designs, mall users are able to meet new friends, strengthen bonds with neighbors and peers, and establish positive social networks with other social groups which in turn thickens what Robert Putnam [63] (1995) refers to as social capital - interaction based on trust and reciprocity believed to be a crucial ingredient for effective economic development and vibrant democracy. It is through this spatial order as well that Tutuban Center empowers its patrons to re-conceptualize the meaning and function of public space to their individual and social lives. Thus, just like Robinson's and Harrison, Tutuban Center is not a mere passive space where people, unmindful of the world around them, find life satisfaction in the consumption of commercially-manufactured goods but an actual event itself, a living environment comprised of diverse and colorful episodes. The lived experiences of mall users in Tutuban Center shows that physical spaces themselves in varying degrees offer opportunities for their users to construct an urban social life independent of the impositions of the dominant forces of the mall and in the process reconstruct their own everyday open spaces.

\subsection{LESSONS LEARNED}

The mainstream literature casts privatized public spaces like malls as a representation of the triumph of private social control over the associational sphere. In these regulated spaces it is assumed that erosion of public life is most likely. However, this study found out that these pessimistic predictions do not fully apply to the three privately-managed shopping malls analyzed in this study. In all of the research sites, spatial designs meant deliberately to restrict activities and "put order on things" inadvertently create conditions that allow mall users to express their own version of order and, in doing so, re-interpret what rightfully constitutes public space. By pursuing activities which they think are appropriately "public", mall users are able play out their own social games independent from the control of the dominant forces of order - the private management and its security forces. Moreover, instead of a homogenous, empty public life, spatial regulations may eventuate, albeit unintentionally, in diverse and heterogeneous urban social sphere.

This study showed that while privatized public spaces like shopping malls are engaged in spatial governance to promote a kind of order and discipline supportive of its commercial and profit-seeking nature, still, contrary to claims of critical sociologists and urban geographers, they do not universally eventuate in a standardization or homogenization of human behavior leading to a precipitous decline of urban public life. Under certain conditions, a more optimistic outcome is possible, that is, the activation of a vibrant, diverse urban public life. Public spaces provoke different meanings and sensations to different people who access them. That is why the regulatory designs and disciplinary practices of the malls "loosen up", allowing the spaces themselves to be reinterpreted by mall-users in the light of their needs and preferences and used as a context for the conduct of their everyday life.

There can be no gainsaying that maintaining order and discipline inside a popular destination such shopping malls has its own efficiency and security benefits. However, equating order and discipline in public spaces with good, quality urban living is not only counter-productive but dangerous to social order itself in the long run. Public spaces have different use and function to different people. Thus, spatial design and planning should facilitate an environment that fit the preferences and needs of their users, not only of their owners. This seems to be counter-intuitive given that shopping malls though accessible to the public remain private properties. But in the context of public spaces that remain under the control and supervision of the city government of Manila, this is a crucial step towards a cost-efficient public space management.

Privatizing public spaces might generate funds for the fulfillment of the city's myriad social obligations. But the local government must realize that open spaces for autonomous social activities is just as important as health or education services. Quality living environment includes open spaces where residents can satisfy their need for active social interaction and public life. Local public policy, financing and design control therefore should support the 
protection and improvement of innovative public spaces which promote interaction between diverse communities of the city. Regarding this matter, a partnership with the private sector holds promise. Both sectors possess their respective comparative advantages in managing public space. Both can work together to plan, design, implement, and maintain public spaces that do not only generate profit but also fulfill a very important obligation to the residents of the city. What are the aspects of this partnership and how can this be brought into fruition is an area worth exploring by future researches.

\section{Acknowledgement}

The researcher is grateful to FEU for sponsoring the conference attendance. Much appreciation to mentors who meticulously combed through the results and design, Dr. Allan de Guzman and Dr. Alelli Sevilla. Appreciation is also given to the shopping mall managers who shared their best practices and gave access to the whole mall.

\section{References}

Allen, J. (2006). Ambient Power: Berlin's Postdamer Platz And The Seductive Logic Of Public Spaces. Urban Studies, 43, 441-455.

Amin, A. (2006). The Good City. Urban Studies, 34, 1009-1023.

Apostol, I. (2007). The Production of Public Spaces: Design Dialectics and Pedagogy. ProQuest.

Atienza, M. (2006). "Local Governments and Devolution in the Philippines," in Philippine Politics and Governance: An Introduction, edited by T. EncarnacionTadem and N. Morada. University of the Philippines Press.

Atkinson, R. (2003). Domestication By Cappuccino Or A Revenge On Urban Space? Control And Empowerment In Management Of Public Spaces. Urban Studies, 40(9), 1829-1843

Avermaete, T., Teerds, H. (2007). Architecture Positions On The Public Sphere. The 2007 Delfi Lecture Series 19(2), 8-23.

Barrett, J. (2012). Museums and the Public Sphere. John Wiley \& Sons.

Banerjee, T. (2001). The Future of Public Space. Journal of the American Planning Association, 67(1), 9-24.

Beck, H. 2009. Linking The Quality Of Public Spaces To Quality Of Life. Journal of Place Management and Development 2(3), $240-248$.

Bickford, S. (2000). Constructing Inequality: City Spaces and the Architecture of Citizenship. Political Theory, 28 (3), $355-76$.

Brown, A. 2006. Contested Space: Street Trading, Public Space, And Livelihoods in Developing Cities. ITDG Publishing.

Button, M. (2003). Private Security And The Policing Of Quasi-Public Space. International Journal of the Sociology of Law, 31, 227-237.

Cattell, V., Dines, N., Gesler, W. and Curtis, S. (2008). Mingling, Observing And Lingering: Everyday Public Spaces And Their Implications For Well-Being And Social Relations. Health and Place, 14, 544-561.

Calderia, T. (1999). "Fortified Enclaves: The New Urban Segregation" in Theorizing The City: The New Urban Anthropology Reader, edited by S. Low. Rutgers University Press.

Castells, M. (2001), "The Space Of Flows" In The Castells Reader On Cities And Social Theory, edited by I. Susser. Blackwell: Oxford.

Crawford, M. (1992). Contesting the Public Realm: Struggles over Public Space in Los Angeles. Journal of Architectural Education, 49(1), 4-9.

Christopherson, S. (1994). "The fortress city: Privatized spaces, consumer citizenship" in Post-Fordism: A Reader, edited by A. Amin. Oxford University Press.

Davis, M. (1992). "Fortress Los Angeles: The Militarization of Urban Space" in Variations on a Theme Park: The New American City and the End of Public Space, edited by Michael Sorkin. Hill and Wang, New York.

Diego" in The Politics of Public Space, edited by S. Low and N. Smith. New York: Routledge.

Melik, R. Aalst, I., Weesep, J. (2009). The private sector and public space in Dutch city centers, Cities 26, $202-209$.

Duff, C. (2011). Networks, resources and agencies: On the character and production of enabling places. Health \& Place, 17, 149-156.

Ehrenreich, B. (2007). Dancing in the Streets: a History of Collective Joy. Granta Books: London.

Estrella, M., Izsatt, N. and Vaventa, J. (2004). Beyong Good Governance: Participatory Governance in the Philippines. QC: Paperchase.

Francis, J., Giles-Corti, B., Wood, L., and Knuiman, M. (2012). Creating sense of community: The role of public space. Journal of Environmental Psychology, 32, 401-409.

Gaffikin, F., Sterrett, K., McEldowney, M., Morrissey, M. \& Hardy, M. (2008) Planning Shared Space for a Shared Future (Belfast: Queen's University and Community Relations Council).

Gill, T. (2001). Putting children first. Architects' Journal 39(27): 103-12.

Goss, J. (1993). The 'magic of the mall': an analysis of form, function, and meaning in the contemporary retail built environment. Annals of the Association of American Geographers 83: 18-47.

Hartig, T. and Staats, H. (2003). Journal of Environmental Psychology, 23: 103-107.

Hedhli, K., Chebat, J. and Sirgy, M. (2011). Shopping Well-Being At The Mall: Construct, Antecedents, And Consequences. Journal of Business Research, doi: 10.1016/j.jbusres.2011.06011.

Hogan, T., Bunell, T.. Pow, C., Permanasari, E., Morshidi, S. (2011). Asian Urbanisms And The Privatization Of Cities. Cities, 29, 59-63.

Hou, J. (2013). Transcultural Cities: Border-Crossing and Placemaking. Routledge

Jessop, B., Peck, J., \& Tickell, A. (1999). "Retooling the Machine: Economic Crisis, State Restructuring, And Urban Politics" In The Urban Growth Machine: Critical Perspectives Two Decades Later, edited by A. Jonas \& D. Wilson. Albany: SUNY Press.

Joung, H. and Miller, N. (2002). Effects Of Older (55+) Female Consumers' Participation In Social Activities On Apparel Shopping Behaviour. Journal of Shopping Center Research, 9, 78-89.

Katz, C. (2006). "Power, Space, and Terror: Social Reproduction and the Public Environment" in The Politics Of Public Space , edited by S. Low and N. Smith. Routledge: New York.

Keyes, C. (2002). Flourishing: Positive Psychology and the Life Well-lived. American Psychological Association.

Korpela, K. and Ylen, M. (2007). Perceived Health Is Associated With Visiting Natural Favourite Places In The Vicinity. Health ad Place, 13(1), 138-151.

Kohn, M. (2004). Brave New Neighborhood: The Privatization of Public Space, New York: Routledge.

Kvale, S. (1996). Interviews: An Introduction to Qualitative Research Interviewing. Thousand Oaks, Sage

Lee, S. (2000). Globalization and The Global City: Meeting The Challenges Of The Twenty-First Century. East Asia, 18(2),18-35.

Lynch, K. (1990). "The Openness Of Open Space” In City Sense And City Design: Writings And Projects of Kevin Lynch, edited by T. Banerjee and M. Southworth. Cambridge, MA: The MIT Press.

Martin, D., McCann, E., and Purcell, M. (2003). Space, Scale, Governance, and Representation: Contemporary Geographical Perspectives on Urban Politics and Policy. Journal of Urban Affairs 25 (2), 113-121.

Merriam, S. B. (1988). Case Study Research: A Qualitative Approach. San Francisco, CA: Jossey-Bass.

Mitchell, D. and Staeheli, L. (2007). Locating the Public in Research and Practice. Progress in Human Geography 31(6), $792-811$.

Mitchell, D. and Staeheli, L. (2006). "Clean and Safe? Property Redevelopment, Public Space, and Homelessness in Downtown San

Mitchell, D. and Staeheli, L.. (2003). The Privatisation Of Public Property The Development Of A Shopping Mall In Sydney And Its Implications For Governance Through Spatial Practices. Urban Policy And Research, 21(3), 249-262.

Milligan, C. and Bingley, A. (2007). Restorative Places Or Scary Places? The Impact Of Woodland On The Mental Wellbeing Of Young Adults. Health 
and Place, 13(4), 799-811.

Newmann, W. Lawrence (2011). Basics of Social Research: Qualitative and Quantitative Approaches, Pearson Education.

Putnam, Robert (1995) "Bowling Alone: America's Declining Social Capital” Journal of Democracy, 6(1), 65-78.

Rose, N. (1999). Powers of Freedom: Reframing Political Thought. Cambridge University Press, Cambridge UK.

Ryan, G. and Bernard, H. (2003). Techniques to Identify Themes. Field Methods, 15 (1), 85-103.

Sampson, R. and Gifford, S. (2010). Place-Making, Settlement And Wellbeing: The Therapeutic Landscapes Of Recently Arrived Youth With Refuge Backgrounds. Health and Place, 16(1), 116-131.

Siu, K. W. M. (2003). Users' Creative Responses And Designers' Roles. Design Issues, 19(2): 64-73.

Smith, N. (2001). 'Global Social Cleansing: Postliberal Revanchism and the Export of Zero Tolerance', Social Justice 28(3): 68-75.

Sorkin, S.. (1992). Variations on A Theme Park: The New American City And The End Of Public Space. New York: Hill and Wang.

Southworth, M. (2005). "Designing the Walkable City." J. Urban Plann. Dev. 131, Special Issue Title Innovating Regulations in Urban Planning and Developmen 246-257.

Stockdale, S., Wells, K., Tang, L., Belin, T., Zhang, L., and Sherbourne, C. (2007). The Importance Of Social Context: Neighborhood Stressors, Stress Buffering Supports And Alcohol, Drug And Mental Health Disorders. Social Science And Medicine, 65(10): 1867-1881.

Van der Ploeg M. Rethinking Urban Public Space in the Context of Democracy and Altruism. Unpublished Document. www.calvin.edu/jks4/city

Volker, B., Flap, H., and Lindberg, S. (2007). When are Neighbourhoods Communities? Community In Dutch Neighbourhoods. European Sociological Review, 23: 99-114.

Voyce, M. (2006). Shopping Malls In Australia The End Of Public Space And The Rise Of 'Consumerist Citizenship’? Journal of Sociology, 42 (3): $269-286$.

Williams, A. (2007). Therapeutic Landscapes. Ashgate Publishers, London.

Woods, P. (2006). Successful Writing for Qualitative Researchers. Routledge.

Yin, R. (2009). Case Study Research: Design And Methods. London: SAGE.

Zukin, S. (1995). Cultures Of Cities. Oxford: Blackwell. 